\title{
Mycobacterium abscessus urinary tract infection: case report
}

\author{
Infecção urinária por Mycobacterium abscessus: relato de caso
}

\section{Authors \\ Jadson Soares Laudelino ${ }^{1}$ (D) Flávio Teles Farias Filho ${ }^{1}$ iD \\ André Falcão Pedrosa Costa ${ }^{1}$ iD \\ Vitorino Modesto Santos ${ }^{2,3}$ (iD \\ ${ }^{1}$ Universidade Estadual de Ciências da Saúde de Alagoas, Maceió, AL, Brasil. \\ ${ }^{2}$ Hospital das Forças Armadas, Brasília, DF, Brasil. \\ ${ }^{3}$ Universidade Católica de Brasília, Taguatinga, DF, Brasil.}

Submitted on: 12/16/2018. Approved on: 03/06/2019.

\section{Correspondence to:}

Vitorino Modesto Santos.

E-mail: vitorinomodesto@gmail.com

DOI: 10.1590/2175-8239-JBN-2018-0260

\section{Abstract}

Urinary tract infection is a serious public health issue that predominantly affects women. In men, it is more often associated with prostatic hyperplasia and bladder catheterization. Urogenital tuberculosis presents with nonspecific with nonspecific symptoms and the diagnosis can be made in the presence of sterile leukocyturia and recurrent infection with acid urine. Non-tuberculous mycobacteria or other non-tuberculosis mycobacteria are opportunistic pathogens that inhabit the soil, water or environment surfaces, and usually cause diseases in immunocompromised individuals. Mycobacterium abscessus is an agent that causes lung, skin and soft tissue hospital infections. Urinary tract infections by this pathogen are rare.

Keywords: Mycobacterium Infections, Nontuberculous; Urinary Tract Infections; Tuberculosis.

\section{Resumo}

Infecção do trato urinário é um sério problema de saúde pública que acomete predominantemente as mulheres. Em homens, está mais relacionada com hiperplasia prostática e cateterismo vesical. A tuberculose urogenital cursa com sintomas inespecíficos e o diagnóstico pode ser aventado na presença de leucocitúria estéril, e infecção recorrente com urina ácida. Micobactérias não tuberculosas ou mycobacteria other than tuberculosis são patógenos oportunistas que habitam o solo, a água ou superfícies do meio ambiente, e geralmente causam doenças em imunodeprimidos. Mycobacterium abscessus é um agente que causa infecções nosocomiais, pulmonares, de pele e de tecidos moles. Infecção urinária decorrente desse patógeno é considerada rara.

Palavras-chave: Infecções por Micobactéria não Tuberculosa; Infecções Urinárias; Tuberculose.

\section{INTRODUCTION}

Urinary tract infections (UTIs) are caused by several microorganisms, and the main pathogen involved is Escherichia coli, followed by Klebsiella pneumoniae, Proteus mirabilis, Enterococcus faecalis and Staphylococcus saprophyticus. ${ }^{1,2}$ Women are more often affected than men, a phenomenon explained by various factors - anatomical or behavioral; in men, prostatic hyperplasia and urinary instrumentation are factors that favor the occurrence of UTIs.

Urogenital tuberculosis (UGTBC) should be considered a differential diagnosis of UTIs; the clinical symptoms are nonspecific, the most common symptoms are dysuria, polaquiuria and back pain, and there may be pyuria and microscopic hematuria. ${ }^{3}$ The UGTBC is based on the growth of the pathogen in urine culture, sown in a specific medium and, rarely, on pathology findings.

Non-tuberculosis mycobacteria (NTM), are those that do not belong to the Mycobacterium tuberculosis (M. tuberculosis and M. bovis) complex, and M. leprae. ${ }^{4}$ More than 125 NTM species that cause diseases in humans have already been identified. ${ }^{4}$ These pathogens are usually isolated from soil and from natural or treated water sources. ${ }^{4}$ There is no evidence of humananimal or inter-human transmission, and the disease results from environmental exposure, although the source of infection is not usually identified. ${ }^{4}$ In developed countries, the 
incidence rate ranges from 1 to 2 cases per 100,000 inhabitants; however, since non-tuberculous mycobacterioses are not compulsorily notifiable diseases, their true incidence is unknown. ${ }^{4}$ Chronic lung infection is the most frequent clinical manifestation, accounting for $90 \%$ of the cases, followed by disseminated disease, lymph node infection and skin or soft tissue infection. ${ }^{4}$ We report a case of an adult man with urinary infection by M. abscessus, a microorganism that has been rarely described as an etiologic agent of UTI.

\section{Case report}

50-year-old man, accountant, from a town in the countryside of Alagoas. He sought medical attention two years before a nephrological evaluation, complaining of pain in the right iliac and suprapubic fossa, nausea, vomiting and intense dysuria. He had no hematuria, fever, or weight loss. After consultation with an urologist, he used ciprofloxacin and tamsulosin for seven days. With no symptom improvement, the treatment regimen with ciprofloxacin was extended for another 14 days. The following exams were ordered in the investigation: urinary tract ultrasonography, prostate-specific antigen dosage and urodynamics, which results remained within the normality range. Urinalysis showed a $\mathrm{pH}$ of 7 and numerous pyocytes; and the erythrocyte sedimentation rate was $75 \mathrm{~mm} / 1^{\text {st }}$ hour. Computed tomography and ultrasound images of the abdomen revealed discrete renal pelvic ectasia and prostate calcifications (Figures $1 \mathrm{~A}$ and $\mathrm{B}$ ).

The initial physical examination of the nephrological evaluation did not detect significant alterations besides discomfort to deep palpation in the hypogastric region. Inflammatory markers, uroculture and EAS were requested for control purposes. Inflammatory markers were altered, leukocyturia persisted in the EAS, and uroculture was repeatedly negative. In this way the possibility of M. tuberculosis urinary infection was raised and specific culture was requested for this infectious agent. Two months later, the patient returned for consultation complaining of persistent dysuria, bladder discomfort (pressure), voiding urgency and nocturia. The uroculture resulted positive for M. abscessus. In the Löwenstein-Jensen solidified medium, fast-growing mycobacteria formed acromogenic colonies with rough-to-smooth morphology. The biochemical tests revealed a reduction of nitrate $(-), \beta$-glycosidase (-), $5 \%$ tolerance to sodium chloride
Figure 1. Abdominal CT (A) and Ultrasound (B) scan images showing mild renal pelvis ectasia and prostate calcifications.

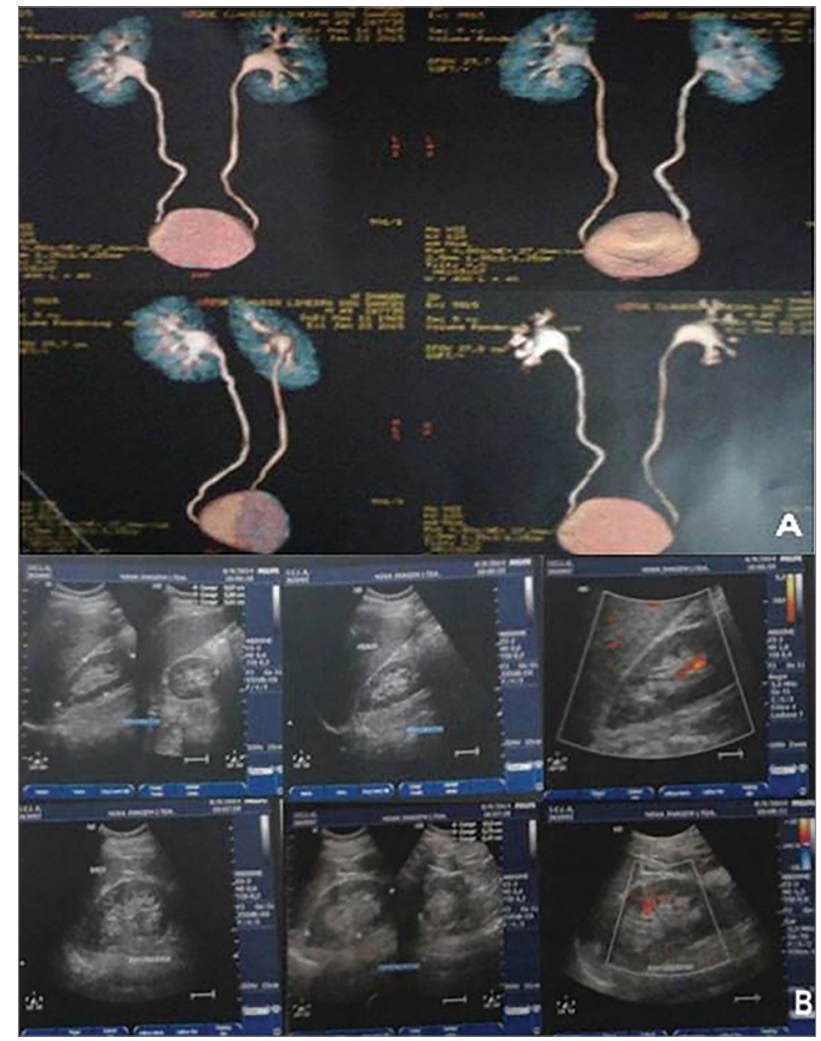

$(+)$, sodium citrate (-), fructose fermentation (-), mannitol fermentation (-); picric acid $(+)$ and Tween 80 hydrolysis (+).

We started treatment with clarithromycin $(500 \mathrm{mg}$ twice daily) and amikacin (15 mg/day), for 18 months. In the fifth month of treatment, the patient remained with urinary symptoms; however, in the tenth month he already showed important improvements. In the eighteenth month of outpatient follow-up, there was no clinical complaint and two urocultures for mycobacteria were negative.

\section{Discussion}

Tuberculosis continues to represent a serious global health problem, ${ }^{5}$ and extra pulmonary involvement can occur in approximately $15 \%$ of the cases. ${ }^{6}$ UGTBC is the second site of this type of involvement and manifests as an insidious clinical picture with no specific symptoms, generally leading to late diagnoses. ${ }^{7}$ Diagnostic confirmation is established by finding M. tuberculosis in urine culture or by pathology examination of tissue samples.

The reported patient had UTI with many symptoms, and did not respond to treatment with the routinely used antibiotics. Considering the persistence of 
the symptoms in the presence of sterile uroculture, tissue calcifications and discrete anatomical alteration of the right pelvis, the hypothesis of UGTBC was proposed and uroculture was requested in a specific medium. The result was positive for $M$. abscessus, one of the nontuberculous mycobacteria that have very rarely been described as the etiology of UTIs.

NTMs are environmental opportunistic pathogens living in soil and drinking water systems. ${ }^{8}$ There are reports of hospital contamination, including epidemic outbreaks. ${ }^{9}$ There is no record of transmission from animals to humans, nor among humans. ${ }^{4}$ Shower water, soil material or pool water may be sources of infection. ${ }^{10}$ NTMs are believed to be acquired from the environment by ingestion, inhalation, or skin contact. ${ }^{10}$ Opportunistic infection is related to immunocompromised patients, such as those infected with $\mathrm{HIV}$, individuals with chronic obstructive pulmonary disease, cystic fibrosis, and sequelae of pulmonary tuberculosis. ${ }^{9,11}$

Diagnosis is made by identifying the mycobacteria, taking into account phenotypic characteristics, biochemical tests and the production of carotenoid pigments, or through the necessary polymerase chain reaction in cases of persistent diagnostic

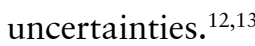

Treatment is prolonged, it has adverse effects and a large number of patients are oligosymptomatic; therefore, the therapeutic decision should take into account the risk of disease progression, the type of NTM involved and the general patient's health. ${ }^{4}$ Therapy is considered successful when symptoms are eradicated or controlled, and control cultures are negative. ${ }^{4}$ Symptom improvement usually occurs after the fourth or sixth month of treatment and cultures are negative between the sixth and twelfth month. ${ }^{4}$ When this does not occur, treatment failure is considered. ${ }^{4}$ Drug therapy should be maintained for 12 months after negative cultures, and thus the average treatment time varies from 12 to 18 months. ${ }^{4}$

Regarding the therapeutic response, NTMs are categorized into two groups: easy to treat (the main representative is $M$. kansasii) and difficult to treat. ${ }^{4}$ The lung disease caused by M. kansasii is usually treated with rifampicin, ethambutol and isoniazid; aminoglycosides are associated in cases of severe or extensive lung involvement. ${ }^{4}$ Macrolides (clarithromycin and azithromycin) are used in difficultto-treat NTMs. ${ }^{4}$ Fast-growing and difficult-to-treat bacteria (including M. fortuitum and M. abscessus) do not usually respond to drug therapy, and treatment should be based on drug sensitivity tests. ${ }^{4}$ Amikacin, clarithromycin, quinolones, doxycycline, imipenem, linezunide, sulfamethoxazole, and tigecycline should be tested. ${ }^{4}$ M. abscessus is a species of rapid growth and multidrug resistance that causes nosocomial infections. ${ }^{14,15}$ Pulmonary, skin and soft tissue infections are the main forms of clinical presentation of the disease. ${ }^{16}$ Contamination may occur after inoculation of the pathogen into skin lesions during small traumas or during surgical procedures. ${ }^{17}$ Disease outbreaks after invasive procedures have been described in the literature, related to different medical procedures: postarthroscopy, laparoscopy and abdominoplasty. ${ }^{14}$ The main hypotheses proposed for these cases of infection are poor sterilization and the use of contaminated water to clean the equipment. ${ }^{14}$

In the treatment of infections caused by this agent, it is mandatory to remove foreign bodies such as prostheses, injured or necrotic tissue. ${ }^{14}$ The pathogen is sensitive to azithromycin, clarithromycin and amikacin. ${ }^{14}$ Studies with in vitro susceptibility tests of growth mycobacterial isolates promptly indicate that amikacin is the drug of choice, followed by fluoquinolones. ${ }^{18}$ For infections of the skin, soft tissue and bone caused by $M$. abscessus, the medicinal product should be clarithromycin $(1,000 \mathrm{mg} /$ day $)$ or azithromycin $(250 \mathrm{mg} /$ day $))$ combined with a parenteral antibiotic (amikacin, imipenem or cefoxitin). ${ }^{19}$ In adults with normal renal function, amikacin is used at doses of 10 to $15 \mathrm{mg} /$ day. ${ }^{19}$ Invasive procedures are indicated for extensive lesions and abscesses, or when there is no proper response from treatment. ${ }^{19}$

\section{Conclusions}

In the present case, it was not possible to establish the contamination mechanism, even after extensive evaluation. Diagnosis was established after the hypothesis of infection by one of these germs based on sterile leukocyturia, which, when detected, should be included in the investigation of this rare pathology.

\section{AUTHORS CONTRIBUTIONS}

Jadson Soares Laudelino, Flávio Teles Farias Filho, André Falcão Pedrosa Costa and Vitorino Modesto Santos contributed substantially to the conception or design of the study; collection, analysis, or interpretation of data; writing or critical review of the 
manuscript; and final approval of the version to be published.

\section{Conflict OF InTEREST}

The authors declare that they have no conflict of interest related to the publication of this manuscript.

\section{References}

1. Flores-Mireles AL, Walker JN, Caparon M, Hultgren SJ. Urinary tract infections: epidemiology, mechanisms of infection and treatment options. Nat Rev Microbiol 2015;13:269-84.

2. Freitas RB, Resende JA, Mendonça BG, Antônio T, Fortunato RS, Oliveira MACA. Infecções do trato urinário de origem hospitalar e comunitária: revisão dos principais micro-organismos causadores e perfil de susceptibilidade. Rev Cient Fagoc Saúde 2016;1:55-62.

3. Merchant S, Bharati A, Merchant N. Tuberculosis of the genitourinary system-Urinary tract tuberculosis: Renal tuberculosis - Part I. Indian J Radiol Imaging 2013;23:46-63.

4. Antunes A, Viveiros F, Carvalho A, Duarte R. Micobacterioses não-tuberculosas - das manifestações clínicas ao tratamento. Arq Med 2012;26:25-30.

5. Merchant S, Bharati A, Merchant N. Tuberculosis of the genitourinary system-Urinary tract tuberculosis: Renal tuberculosis - Part II. Indian J Radiol Imaging 2013;23:64-77.

6. Delgado DRD, Moraes DN, Carneiro PGS, Pappini P, Vieira MVL, Dambroz AT, et al. Polaciúria incapacitante para a vida usual. Relato de tuberculose da bexiga. A tuberculose permanece no rol do diagnóstico diferencial da maioria das doenças. Rev Med Minas Gerais 2013;23:399-404.

7. Júlio C, Amaral N, Biscaia I, Torrezão I, Fatela A. Tuberculose genital: uma causa rara de hemorragia pós-menopausa. Acta Med Port 2010;23:723-6.

8. Falkinham JO 3rd. Surrounded by mycobacteria: nontuberculous mycobacteria in the human environment. J Appl Microbiol 2009; 107:356-67.
9. Senna SG, Marsico AG, Vieira GBO, Sobral LF, Suffys PN, Fonseca Lde S. Identification of nontuberculous mycobacteria isolated from clinical sterile sites in patients at a university hospital in the city of Rio de Janeiro, Brazil. J Bras Pneumol 2011;37:21-6.

10. Nishiuchi Y, Iwamoto T, Maruyama F. Infection Sources of a Common Non-tuberculous Mycobacterial Pathogen, Mycobacterium avium Complex. Front Med (Lausanne) 2017;4:27.

11. Moore JE, Kruijshaar ME, Ormerod LP, Drobniewski F, Abubakar I. Increasing reports of non-tuberculous mycobacteria in England, Wales and Northern Ireland. 1995-2006. BMC Public Health 2010;10:612.

12. Bombarda S, Chimara E, Seiscento M, Oliveira MLV, Ferrazoli L, Galesi VMN. Recomendações para o diagnóstico e tratamento das micobacterioses não tuberculosas no estado de São Paulo. São Paulo: Secretaria de Estado da Saúde; 2011.

13. Wildner LM, Nogueira CL, Souza BS, Senna SG, Silva RM, Bazzo ML. Micobactérias: epidemiologia e diagnóstico. Rev Patol Trop 2011;40:207-29.

14. Carvalho NFG, Ferrazoli L, Riveron MBA, Chimara E. Caracterização dos surtos causados pelo grupo Mycobacterium abscessus. Rev Inst Adolfo Lutz 2012;71:228-36.

15. Lee MR, Sheng WH, Hung CC, Yu CJ, Lee LN, Hsueh PR. Mycobacterium abscessus Complex Infections in Humans. Emerg Infect Dis 2015;21:1638-46.

16. Petrosoniak A, Kim P, Desjardins M, Lee BC. Successful treatment of a prosthetic joint infection due to Mycobacterium abscessus. Can J Infect Dis Med Microbiol 2009;20:e94-6.

17. Song JY, Son JB, Lee MK, Gwack J, Lee KS, Park JY. Case series of Mycobacterium abscessus infections associated with a trigger point injection and epidural block at a rural clinic. Epidemiol Health 2012;34:e2012001.

18. Gayathri R, Therese KL, Deepa P, Mangai S, Madhavan HN. Antibiotic susceptibility pattern of rapidly growing mycobacteria. J Postgrad Med 2010;56:76-8.

19. Griffith DE, Aksamit T, Brown-Elliott BA, Catanzaro A, Daley C, Gordin F, et al.; ATS Mycobacterial Diseases Subcommittee; American Thoracic Society; Infectious Disease Society of America. An official ATS/IDSA statement: diagnosis, treatment, and prevention of nontuberculous mycobacterial diseases. Am J Respir Crit Care Med 2007;175:367-416. 